\title{
AS PRETAS MINAS DO ROSÁRIO NAS MARGENS DA LIBERDADE: MOBILIDADE SOCIAL E HERANÇAS DA DIÁSPORA (SÃO JOÃO DEL-REI, SÉCULOS XVIII E XIX)
}

\section{Leonara Lacerda Delfino ${ }^{1}$}

\begin{abstract}
Todos os acontecimentos, do nascimento à morte, eram comemorados nas confrarias e quem estivesse fora delas seria olhado com desconfiança, privado do convívio social, quase um apátrida dentro dos grupos que se reuniam em associações (...). O desligamento de uma confraria representava grave problema, colocando a pessoa à margem da sociedade, significando tremendo castigo. Não parecia admissível que alguém pudesse viver sem estar unido a um desses grupos e, castigo ainda maior, morrer fora de um deles. ${ }^{2}$
\end{abstract}

As irmandades do Rosário serviram como espaço crucial de atuação das mulheres forras africanas na sociedade escravista, regida pelo ideal de estratificações sociais do antigo regime, em que a capacidade se filiar em maior número de confrarias representava um sinal de pujança do indivíduo $e$ sua necessidade de expandir suas alianças sociais de reciprocidade, através do auxílio mútuo viabilizado pela vida associativa. Não obstante, aderir em um sodalício significava não só a obtenção de status, mas, sobretudo, o amparo espiritual e material, o pertencimento a um "nós" mais coeso, ou seja, o "estar" em uma família ritual proporcionava ganhos efetivos ao indivíduo em situação de exílio, como a caridade material e espiritual a seus membros, além do partilhamento de símbolos, signos, práticas, obrigações, crenças e o sentimento aglutinador de devoção a um santo patrono protetor. $\mathrm{O}$ espetáculo da religiosidade barroca colocava o confrade em um cotidiano intenso de atividades devocionais, onde a vida supraterrena se espetacularizava constantemente pelos rituais litúrgicos; o "céu" parecia descer a terra, para usarmos da alegoria de Affonso Ávila ${ }^{3}$, ao tratar sobre o "lúdico e as projeções do mundo barroco".

Nesse sentido, as confrarias católicas cumpriram um papel de reintegração social e identitária no contexto da diáspora atlântica. Ainda que vinculadas ao discurso hegemônico de catequização no Ultramar, as irmandades negras serviram como espaço para a construção de sentidos inéditos de significação das práticas vivenciadas no Novo Mundo, pois os seus protagonistas elaboraram novas leituras, reinterpretaram memórias ${ }^{4}$ e atribuíram concepções imprevisíveis aos símbolos católicos. Esta reinterpretação simbólica ${ }^{5}$ dependeu, efetivamente, de uma complexa interação entre as africanidades ou heranças culturais e as "invenções" fruto da miscigenação/hibridismo cultural.

Com efeito, as experiências situacionais foram significadas a partir da complexa tensão entre as orientações cognitivas trazidas do outro lado da Kalunga ${ }^{6} e$ as visões de mundo estabelecidas nos processos coercitivos e adversos impostos pela diáspora. Deste modo, o parentesco confraternal viabilizou redes de solidariedade, a reinvenção da existência a partir do sentimento de coesão, mesmo diante das tensões e divisões étnicas e sociais ocorridas em diversos espaços de sociabilidade no Ultramar. O sentimento de pertença grupal ofereceu conforto existencial diante da desagregação do

\footnotetext{
${ }^{1}$ Pós-doutoranda em História (PPGH/UNIMONTES). Bolsista CAPES/PNPD. Doutora e Mestre em História pela Universidade Federal de Juiz de Fora.

${ }^{2}$ SCARANO, Julita. Devoção e Escravidão: A Irmandade de Nossa Senhora do Rosário dos Pretos no Distrito de Diamantina no século XVIII. São Paulo: Editora Nacional, 1978, p. 37.

${ }^{3}$ ÁVILA, Affonso. O lúdico e as projeções do mundo barroco. $2^{\text {a }}$ Edição. São Paulo: Editora Perspectiva, 1980.

${ }^{4}$ Faço alusão ao termo "heranças e recordações" cunhado por Slenes, ao tratar sobre as memórias recriadas no contexto atlântico. Cf.: SLENES, Robert. Na senzala uma flor. Esperanças e recordações na formação da família escrava. Brasil, Sudeste, século XIX. Rio de Janeiro: Nova Fronteira, 1999.

${ }^{5}$ Segundo Chartier, os processos de apropriação e de reinterpretação simbólica não coadunam com a percepção de passividade de "leitura" da realidade, onde é possível identificar um emissor e receptor das representações, como se as mensagens transmitidas tivessem nelas sentidos intrínsecos, totalmente independentes da significação atribuída pelos sujeitos. Sendo assim, "anular o corte entre produzir e consumir é antes de mais afirmar que a obra só adquire sentido através da diversidade de interpretações que constroem as suas significações." Cf.: CHARTIER, Roger. História Cultural: Entre práticas e representações. Lisboa: Difel, 2002, p. 59.

${ }^{6}$ Um dos sentidos do termo Kalunga pode ser entendido como travessia atlântica, cf.: SLENES, Na senzala, uma flor..., p. 246
} 
exílio, isto é, estabeleceu um amparo psíquico para o enfrentamento das agruras do cativeiro e da sociedade altamente estratificada, além de propiciar a "maximização da boa-ventura" e da prevenção da desventura, almejando o fortalecimento de uma relação interpessoal de troca com as divindades, através da adoção dos santos católicos, enquanto entidades capazes de trazer soluções cotidianas $e$ curas aos malefícios terrenos e espirituais. ${ }^{7}$

Nessa perspectiva, as mulheres irmãs cumpriram um papel fundamental na sedimentação dos laços horizontais e verticais no interior das irmandades católicas. Embora afastadas formalmente pela linguagem oficial dos compromissos das instâncias decisórias desses sodalícios, ocuparam lugar de destaque nos espaços tido informais das confrarias. Estas adquiriram, em grande parte, projeções nos reinados, serviram como as principais articuladoras da mobilização e organização dos festejos, mobilizaram esmolas, potencializaram as rendas materiais dos sodalícios, através da capacidade que dispunham em dispensar esmolas vultuosas.

Em São João del-Rei, a irmandade do Rosário, fundada em 1708 contou com a participação maciça das mulheres entre seus matriculados. Do total de 1431 entrantes localizados entre o período de 1782 a 1850, as mulheres representaram a maioria, com de 55,4\% da soma de matriculados. ${ }^{8}$ Muitas destas irmãs também se destacaram na ocupação dos cargos de juizados, embora o discurso oficial dos compromissos se preocupou em restringir os "espaços de mandos" destas mulheres, relegando à elas o papel de limpeza do templo, das alfaias, das opas, retirando-lhes o poder de voto nas instâncias decisivas discutidas pela mesa diretiva, órgão responsável pela gerência da irmandade.

Este silenciamento referente às atividades das irmãs e a tentativa de empurrá-las para as tarefas tidas como subalternas, pode ser notado pela reforma do estatuto da Irmandade do Rosário de São João, quando uma de suas cláusulas prescrevia, em 1841 que essas devotas deveriam se ocupar "naquilo que [fosse] compatível ao se sexo", como os cuidados com o "asseio e limpeza do templo e de todas as suas alfaias e paramentos", fiscalizados pelo irmão zelador. As irmãs de mesa também não possuíam, formalmente, direito ao sufrágio dos assuntos votados pela cúpula diretória, uma vez que só os "mesários do sexo masculino" tinham poder de voto e, nenhuma ação poderia ser decidida sem os cinco principais mesários: o rei, o provedor, o secretário, o tesoureiro e o procurador. ${ }^{9}$

Não obstante, além do asseio da e limpeza da capela e de seus paramentos e alfaias, as irmãs mesárias ${ }^{10}$ tinham por incumbência os cuidados dirigidos aos confrades doentes, moribundos, presidiários. Essas irmãs exerciam um papel fundamental, junto à juíza e à rainha no que se refere aos preparativos das festas, nas armações de andores, arrumações dos altares e organização dos banquetes. De acordo com os apontamentos estatuários, as mesárias foram excluídas formalmente das instâncias decisórias por não possuírem votos nas juntas administrativas, assegurados somente aos irmãos do sexo masculino. ${ }^{11}$ No entanto, ao confrontarmos essa informação com os dados extraídos com os livros de matrículas, pudemos verificar que a maioria dos cargos de reinado foi ocupada por mulheres, ou seja, dos nomes listados entre os reis e rainhas, havia 27 mulheres para 21 homens. Entre os cargos de juizados, receberam notável destaque e na própria participação do corpo de matriculados perfaziam, entre o período de 1782 a 1850, a representação de 55,4\% do total de 1431

\footnotetext{
${ }^{7}$ DELFINO, Leonara Lacerda, O Rosário dos Irmãos Escravos e Libertos: Fronteiras, Identidades e Representações do Viver e Morrer na Diáspora Atlântica. Freguesia do Pilar-São João Del-Rei (1782-1850). Tese (Doutorado em História). Universidade Federal de Juiz de Fora. Juiz de Fora-MG, 2015.

${ }^{8}$ Arquivo da Igreja de Nossa Senhora do Rosário de São João del-Rei, AINSR-SJDR, Livros de Entradas (1782-1850).

${ }^{9}$ Arquivo da Matriz de Nossa Senhora do Pilar de São João del-Rei, AMNSP- SJDR, Compromisso da Irmandade de Nossa Senhora do Rosário dos Pretos de São João del-Rei (1841), Cap. 2 e Cap. 6, Parágrafo 7, Fl. 4-8.

${ }^{10}$ AMNSP- SJDR, Cap. 6, Parágrafo 7, Compromisso da Irmandade de Nossa Senhora do Rosário dos Pretos de São João del-Rei (1841).

${ }^{11}$ Cf.: AMNSP- SJDR, Cap. 6, Parágrafo 7, Compromisso da Irmandade de Nossa Senhora do Rosário dos Pretos de São João del-Rei (1841). Em consulta ao compromisso do Rosário de Arraial de Brumado observamos em seu artigo quinto do capitulo oitavo que eram funções atribuídas às juízas e irmãs: "lavar a roupa da igreja pertencente a irmandade, (...) permitir andar por mãos das irmãs concorrendo a Irmandade com materiais necessários para que venha lavada e passada a ferro $e$ com todo asseio que pede semelhantes alfaias. Mandará varrer e lavar a Igreja quando for necessário e assim também arear os móveis de prata, cobre e estanho para a decência da Igreja (...)". No entanto, as mulheres juízas dessa associação possuíam votos nas juntas referentes somente aos atos festivos e recebiam oito missas em sufrágio pelo seu trabalho, um número maior do que fora reservado aos mordomos (06 missas). Cf.: AMNSP- SJDR, Cap. 8, Artigos $5^{\circ}$ e $6^{\circ}$, Compromisso da Irmandade do Rosário dos Homens Pretos (São Gonçalo do Amarante de Arraial do Brumado, Filial da Matriz de São João del-Rei), 1815.
} 
entrantes. $^{12}$

Marcos Aguiar ${ }^{13}$, ao analisar os livros de receitas das irmandades negras das comarcas de Ouro Preto e Sabará, constatou que as mulheres entrantes exerciam um papel central na sustentação material do culto desses sodalícios, mais precisamente em relação à contribuição das esmolas $e$ anuidades. No Rosário de Casa Branca, por exemplo, contribuíram as irmãs "com mais da metade das receitas" de toda a irmandade. Todavia, não eram as mesmas beneficiadas nas possibilidades de inserção aos postos diretivos, nem recompensadas, com a mesma equidade, nos benefícios espirituais. Segundo o autor, essas associações foram "sustentadas pelas mulheres e administradas por homens", reproduzindo, portanto, a tônica das relações assimétricas de gênero presentes na sociedade colonial.

A despeito dessas conclusões, consideramos que esses argumentos precisam ser matizados, primeiramente por entendermos que as relações de gênero eram mais acentuadas entre a elite branca do que entre os grupos subalternos entre si. Não podemos esquecer o protagonismo exercido pelas pretas mercadoras tão bem estudado por Sheila Faria ${ }^{14}$. Se as mulheres irmãs fossem tão submissas ao ponto de não participarem de modo efetivo das instâncias decisórias, como explicar a ameaça de "levante" no interior da confraria de Santo Elesbão e de Santa Ifigênia incitada pela rainha da irmandade? ${ }^{15}$

Ademais, o aprofundamento da questão sobre a inserção feminina nas agremiações de cor foi feito por Lucilene Reginaldo, ${ }^{16}$ ao demonstrar em seu estudo que as mulheres representavam $72,1 \%$ dos assentados entre os associados do Rosário das Portas do Carmo de cidade de Salvador no período de 1719-1826. Entre os libertos entrantes, representaram o sexo feminino $79,2 \%$ dos assentados desta condição social. A participação feminina, na perspectiva da autora, não fazia dessas irmãs "meros adornos" no cotidiano das associações negras, pois por meio delas, se articulava o principal acontecimento público da vida associativa, impresso na realização do festejo à santa padroeira. Além disso, Sheila Faria nos lembra sobre o potencial adquirido pelas mulheres forras quanto à sua capacidade em amealhar recursos e reverter parte do seu pecúlio em esmolas elevadas às irmandades, alcançando, assim, cargos como rainhas, juízas, mesárias, irmãs remidas, ou de juizados de promessa. As irmãs, muitas vezes, saíram à frente tanto em contribuições individuais, quanto nos peditórios coletivos quando a irmandade fazia "girar a caixinha do santo", garantindo, deste modo, a arrecadação de donativos da festa. As devotas também exerciam o trabalho manual da confecção de mortalhas (em amparo as irmãos que morriam na miséria) e do conserto das opas brancas, utilizadas em ocasião das atividades celebrativas. ${ }^{17}$

Antônia Aparecida Quintão ${ }^{18}$ observou o destaque do engajamento dos confrades do sexo feminino, ao notar o contraste dessas associações negras com as devoções brancas "cuja predominância parece ter sido sempre masculina". Fernanda Pinheiro, ${ }^{19}$ por outro lado, chamou

\footnotetext{
${ }^{12}$ AINSR-SJDR, Livros de Entradas (1782-1850).

${ }^{13}$ AGUIAR, Marcos. Negras Minas Gerais: uma história da diáspora africana no Brasil Colonial. Tese (Doutorado em História). USP: São Paulo, 1999, p. 303

${ }^{14}$ FARIA, Sheila de Castro. Sinhás Pretas, Damas Mercadoras: as pretas minas nas cidades do Rio de Janeiro e de São João del-Rei (1700-1850). Tese para concurso de Professor Titular em História do Brasil. Niterói, UFF, 2004, p. 233.

${ }^{15}$ Eu me refiro à viúva do rei Inácio Gonçalves do Monte que, na ocasião da morte do seu marido, se recusou a devolver as chaves do cofre da irmandade e se auto-proclamou sucessora do reinado. Deste conflito surgiram duas facções: a da rainha (acusadas de superstições e práticas gentílicas) e a do regente, escolhido pelo antecessor (Francisco Alves de Souza). Durante a querela, a rainha adquire o apoio do vice-rei do Rio de Janeiro e consegue, com este suporte político, impedir que "o regente vá com sua folia às igrejas do Rosário ao Santo Elesbão." Segundo Soares, "um dos pontos mais interessantes dessa arenga é a força que as tão contestadas mulheres demonstram ter no interior de um tipo de agremiação onde o poder está nitidamente concentrado nas mãos dos homens. Nos estatutos da devoção das almas as mulheres são descritas como orgulhosas, amigas de enredo, perturbadoras da paz e sossego". Cf.: SOARES, Mariza de Carvalho. Devotos da cor: Identidade étnica, religiosidade e escravidão no Rio de Janeiro, século XVIII. Rio de Janeiro: Civilização Brasileira, 2000, p. 205.

${ }^{16}$ REGINALDO, Lucilene. Os Rosários dos Angolas. Irmandades de africanos e crioulos na Bahia Setecentista. São Paulo: Alameda, 2011, p. 330

${ }^{17}$ REIS, João José. A Morte é uma Festa: ritos fúnebres e revolta popular no Brasil do século XIX. São Paulo: Companhia das Letras, 1991, p. 58.

${ }^{18}$ QUINTÃO, Antônia Aparecida. Lá vem meu parente: As Irmandades de pretos e pardos no Rio de Janeiro e Pernambuco. (Século XVIII). São Paulo: Annablume: Fapesp, 2002, p. 89.

${ }^{19}$ PINHEIRO, Fernanda Aparecida. Confrades do Rosário: Sociabilidade e Identidade Étnica em Mariana - Minas Gerais, 1745-1820. Dissertação (Mestrado em História). Universidade Federal Fluminense, Niterói-RJ, 2006, p. 63.
} 
atenção ao fato dessas irmãs não dependerem de uma filiação masculina para registrarem seus assentos nessas irmandades. Para a autora, essas mulheres (principalmente as forras) "possuíam autonomia para firmarem suas filiações," não dependendo, portanto, da autorização de algum vínculo masculino, como ocorria nas associações de elite em que as irmãs só entrariam sob autorização do cônjuge. Mulheres sós ou casadas (na condição de libertas) assentavam suas matrículas individuais, independentes dos seus parceiros ou outra figura externa, o que sugere a autonomia financeira dessas irmãs. Já as escravas, precisavam da autorização dos seus senhores, mas na maioria das vezes seus registros de filiação não indicavam o pagamento da taxa de entrada feita pelo seu proprietário. Tal apontamento não exclui a possibilidade dessas matrículas serem pagas com recursos próprios dessas cativas, mediante o seu envolvimento com os ofícios vinculados ao sistema de jornais ou de ganho.

Diante dessas assertivas, não concordamos integralmente com a afirmação de que as associações negras eram "sustentadas por mulheres, mas administradas por homens". Sugiro que esta argumentação seja relativizada pelo fato das instâncias decisórias da irmandade não se construírem exclusivamente pelo veículo formal do estatuto, mas também pelo âmbito das esferas vivenciadas no cotidiano do grêmio em que se aplicavam essas orientações normativas ou até mesmo as confrontavam. Em análise dos depoimentos testamentários das mulheres forras destacadas na realeza ou no juizado da irmandade, pudemos verificar como essas irmãs articularam redes, arregimentaram "por mercê" 20 seus filhos, parentes, maridos e aliados na inserção da confraria; legaram verdadeiros patrimônios (casas de moradas, joias, etc.) à Nossa Senhora e arquitetaram alianças decisivas na condução espiritual vivenciada no espaço sagrado da vida devocional, assunto a ser tratado no item a seguir.

\section{As heranças materiais $e$ imateriais: $O$ protagonismo das irmãs forras}

Uma das forras proeminentes na atuação hierárquica da irmandade foi a preta Josefa da Costa Gouvêa, natural da Costa da Mina. Conforme seu relato testamentário, assinado a rogo por Guilherme José da Costa em 1797, a irmã morava na Vila de São João del-Rei e foi casada com Cristóvão Fernandes Preto Forro "já falecido" durante a redação do seu testamento. Deste matrimônio não contraíram filho algum, por este motivo não deixou a viúva "herdeiros forçados". Declarou a liberta ter servido à Senhora do Rosário como da juíza da irmandade e por isso lhe deixava um "recipiente de ouro encravado de diamantes". Disse ainda, querer cinco missas pela sua alma no dia em que esta partisse deste mundo terreno. Deixou a juíza no arrolamento de seus bens, alguns pares de brincos, pedras preciosas, joias, roupas de seda, "alguns móveis" e ouro em espécie lavrado. A quantia de ouro estava penhorada nas mãos de João Nunes da Graça Preto Forro, morador da Rua da Cachaça, no valor de 14 oitavas, pelo empréstimo que fez em dez oitavas e três quartos, segundo seu depoimento testamentário. ${ }^{21}$

Ademais devia empréstimos também às forras Perpétua Teixeira da Silva, pelo botão de ouro que se achava "em suas mãos", e à Joana Nunes (moradora em casa de Afonso), pelo valor de doze vinténs. Do restante dos seus bens declarou que sua "roupazinha" de uso deveria ser doada em caridade às mulheres pobres que andassem a mendigar pelas ruas de São João del-Rei e por fim, anunciou que sua herdeira seria sua testamenteira nomeada, Ana Marcelina da Silva. ${ }^{22}$

O mesmo nome de Perpétua Teixeira da Silva, uma das credoras da forra Josefa da Costa Gouvêa, foi mencionado ocupando os cargos de rainha e juíza do Rosário de São João del-Rei, pelo testamento em que a mesma abriu em 1792. A preta forra, procedente da Costa da Mina, declarou em seu depoimento ser solteira e mãe de dois filhos (Joaquina Teixeira Crioula - casada que foi com Miguel Barbosa - e Helena Teixeira da Cruz Parda, viúva de João de Toledo). Arrolou entre seus bens, uma morada de casas na qual residia (situada na Rua Direita) com quatro escravos: Quitéria de Nação Mina

\footnotetext{
${ }^{20}$ Agraciar "por mercê" a entrada de um irmão significava uma cortesia por parte de reis, rainhas ou altos dignitários da irmandade para a matrícula destituída do pagamento do valor em esmola, para maiores informações, ver: DELFINO, $O$ Rosário dos Irmãos Escravos e Libertos... p. 294.

21 AMSSP-SJDR, Livro de Óbitos (1800, mai-1804, mar), Testamento de Josefa da Costa Gouvêa aberto em 12/02/1797, anexo ao Assento de Óbito de Josefa da Costa Gouvêa Preta Mina de 25/02/1802.

22 AMSSP-SJDR, Livro de Óbitos (1800, mai-1804, mar), Testamento de Josefa da Costa Gouvêa aberto em 12/02/1797, anexo ao Assento de Óbito de Josefa da Costa Gouvêa Preta Mina de 25/02/1802.

374 SÆCUlUM - Revista DE HistóRIa [39]; João Pessoa, jul./dez. 2018.
} 
e sua filha Maria Parda, Antônio Crioulo e Domingos Crioulo. ${ }^{23}$

Na distribuição da partilha, deixou à sua irmandade do Rosário o legado de dez oitavas de ouro, além do pagamento dos anuais pendentes. Determinou à testadora que seu corpo fosse sepultado na Capela do Rosário, onde ocupou os "cargos de juíza e rainha da mesma senhora" e que seu féretro fosse conduzido pelo seu "Reverendo e alguns sacerdotes". Além disso, instituiu suas filhas - Helena e Joaquina - por herdeiras, e pediu aos seus testamenteiros que o remanescente de sua terça parte fosse distribuído em missas ditas no altar do Rosário pela salvação de sua alma. Ainda declarou em seu relato, a transferência do "papel de coartamento" à escrava Quitéria, pelo tempo máximo de dois anos, sob a condição de que se a escrava não lhe repassasse até o falecimento a quantia afirmada em acordo, voltaria a escrava para o montante dos seus bens. ${ }^{24}$

Com a cativa Hilária, a senhora forra foi mais tolerante, ao permiti-la o tempo de cinco anos para a quitação de sua quantia, avaliada em cem oitavas de ouro. Esta prerrogativa contava, por fim, com "mais algum tempo de equidade", caso a mesma não conseguisse quitar a dívida no tempo de cinco anos. Perpétua Teixeira da Silva faleceu em primeiro de novembro de 1800, recebeu todos os sacramentos e foi encomendada e sepultada dentro da Capela do Rosário. ${ }^{25}$

Outra trajetória - que se confunde em alguns pontos com os fragmentos apresentados pelos depoimentos deixados pelas forras Josefa e Perpétua - foi a de Ana de Castilho. Assim como as outras duas irmãs, Ana liberta também tinha procedência da Costa da Mina. Viúva de José da Costa Gouvêa, a irmã assumiu "vários cargos" diretivos da irmandade e demonstrou ter construído um patrimônio capaz de ser transmitido até mesmo a seus netos nascidos no Brasil. Todos os seus bens foram avaliados em casas que tinha atrás da Rua do Carmo, uma chácara (alocada nos subúrbios da Vila de São João del-Rei) e escravos. ${ }^{26}$

Declarou, a forra, ter sido os seus bens adquiridos "pelo seu trabalho e de seu marido José da Costa". E durante o tempo que viveu com ele, gerou quatro filhos, "todos do seu dito marido", a saber: Joaquim, José, Luiza e Maria da Costa. Desses, apenas Luiza se achava viva até aquele momento e a mesma foi nomeada como primeira testamenteira e herdeira de seus bens. Em segundo lugar, como testamenteiro, viria o seu neto Pedro Rodrigues e em terceiro, a sua neta e afilhada, Manoela Rodrigues. Na falta de Luiza, esses passariam a representar seus herdeiros diretos pela obediência em que eles se dirigiam a sua avó. Ainda justificou, Ana de Castilho, ter muita consideração por sua filha, pelo fato desta ter lhe prestado, com muito afeto, todos os auxílios em suas enfermidades. Por isso avisava à testamenteira e filha que o valor descontado acerca do dote do casamento (herança que lhe adiantou) não fosse levado em conta naquele momento, pois era sua última vontade retribuir os cuidados que recebeu em seu estado de fragilidade. ${ }^{27}$

E por fim, declarou que deixava "liberta de hoje e sempre", pela promessa que fez a seu marido, a sua escrava Ana Crioula, filha de Ana Nagô também sua cativa. No entanto manteria, com aquele testamento, a mãe da dita crioula em cativeiro, em razão de sua desobediência e infidelidade, lhe revogando, portanto, o contrato de coartação que havia feito em prol de sua libertação. Ana de Castilho faleceu em 18 de setembro de 1802, recebendo todos os sacramentos, sendo encomendada pelo reverendo pároco, acompanhada pelos seus irmãos de devoção e sepultada dentro da Capela do Rosário dos Pretos, conforme prescrito em seu testamento. Recebeu a irmã forra, em sufrágio, dez missas pela sua alma, e dedicou outras dez em benefício à alma de seu marido. ${ }^{28}$

A próxima testadora a ser apresentada, Maria Correa de Andrade, também foi ocupante de "vários cargos" no Rosário de São João del-Rei. Preta forra da Costa da Mina, viúva de Alexandre Correa de

\footnotetext{
${ }^{23}$ AMSSP-SJDR, Livro de Óbitos (1800, mai-1804, mar), Testamento de Perpétua Teixeira da Silva aberto em 15/06/1792, anexo ao Assento de Óbito de Perpétua Teixeira da Silva, 01/11/1800.

${ }^{24}$ AMSSP-SJDR, Livro de Óbitos (1800, mai-1804, mar), Testamento de Perpétua Teixeira da Silva aberto em 15/06/1792, anexo ao Assento de Óbito de Perpétua Teixeira da Silva, 01/11/1800.

${ }^{25}$ AMSSP-SJDR, Livro de Óbitos (1800, mai-1804, mar), Testamento de Perpétua Teixeira da Silva aberto em 15/06/1792, anexo ao Assento de Óbito de Perpétua Teixeira da Silva, 01/11/1800.

${ }^{26}$ AMSSP-SJDR, Livro de Óbitos (1800, mai-1804, mar), Testamento de Ana de Castilho Preta Mina aberto em 10/04/1802, anexo ao Assento de Óbito de Ana de Castilho, 18/09/1802.

${ }^{27}$ AMSSP-SJDR, Livro de Óbitos (1800, mai-1804, mar), Testamento de Ana de Castilho Preta Mina aberto em 10/04/1802, anexo ao Assento de Óbito de Ana de Castilho, 18/09/1802.

${ }^{28}$ AMSSP-SJDR, Livro de Óbitos (1800, mai-1804, mar), Testamento de Ana de Castilho Preta Mina aberto em 10/04/1802, anexo ao Assento de Óbito de Ana de Castilho, 18/09/1802.
} 
Andrade Preto Mina, instituiu a testadora, assim como fez Ana de Castilho, seus filhos e netos como herdeiros dos seus bens. Entre seus filhos listados havia quatro filhos legítimos (Antônia, Manoel, Francisco e Natália) e dois naturais (José e Vitória, esta última já falecida). Os três primeiros foram mencionados como testamenteiros e a neta Maria, filha da falecida Vitória, beneficiária de um dote para seu casamento, por meio da doação de um escravo - Manoel de Nação Angola - a pedido que fez o seu genro (pai de Maria), Luciano Rodrigues de Carvalho. Além de Maria, mais cinco netos foram beneficiados na realização da partilha de bens, todos, filhos de Vitória. ${ }^{29}$

Maria Correa de Andrade também declarou possuir terras de minerar, sita à paragem do Canal da Vila de São João, em que a preta mina havia adquirido através de uma sociedade feita com o Capitão José de Souza Gonçalves e Antônio João Crioulo, pelo trato lavrado em nota do tabelião. Mencionou ser proprietária de três escravos: José Angola, Francisco Angola e Hilária de Nação Mina. Esta última recebeu, por recomendação do seu falecido marido, a carta de liberdade pela metade do valor do seu preço de mercado, no entanto, "estaria isenta de toda escravidão" se não deixasse de assistir seus filhos durante o tempo de quatro anos. Reiterou Maria Correa que os mesmos deveriam tratá-la com a mesma caridade em que a tratou durante sua vida. Faleceu com todos os sacramentos em 11 de janeiro de 1791. Durante o seu funeral foram distribuídas as esmolas de dois vinténs para cada um dos doze pobres que estiveram presentes no acompanhamento do féretro. ${ }^{30}$

A reciprocidade traçada entre as irmãs libertas e seus aliados adquiridos dentro e fora da irmandade foi, repetidas vezes, externalizada pelos depoimentos autobiográficos dos testamentos. Isso demonstra o protagonismo feminino exercido nos mundos do trabalho, nas margens da liberdade, nos postos prestigiados de rainhas, juízas e de irmãs mesárias. $\mathrm{Na}$ ânsia de se destacarem naquela sociedade altamente hierarquizada, essas mulheres mostraram a necessidade de retribuir ao Rosário, a solidariedade que recebiam na vida e na morte. Um caso paradigmático foi demonstrado por Ana de Oliveira, natural da Costa da Guiné e casada com Manoel Pinto, legou uma casa de morada para o usufruto de seus escravos libertados. Segundo esta devota do Rosário todos os bens adquiridos por sua "indústria e suor de seu trabalho" e, depois da morte desses beneficiados, o patrimônio deveria ser transferido à irmandade em que pertenceu, conforme o seu testamento aberto em 1779:

Declaro que dos bens que possuo ao presente são setenta e duas oitavas de ouro em pó, quarenta e duas oitavas em ouro lavrado e uma barrinha de ouro de quarenta e uma oitavas. Declaro que também possuo uma morada de casas na Rua da Cachaça, nas quais estou morando, as quais deixo aos meus dois escravos que foram Manoel e Maria de Nação Benguela para os mesmos nelas viverem e morarem, enquanto forem vivos e, por falecimento de ambos, deixo a referida morada de casas à Irmandade do Rosário desta Vila para sempre e por isso meu testamenteiro as não dará ao Inventário (...). Declaro que deixo uma saia preta e uma baeta de lemiste a dita minha escrava que foi por nome de Maria de Nação Benguela e a mais roupa do meu uso, ordeno que se reporta por alguns pobres que me acompanharem à sepultura logo que eu falecer (...). ${ }^{31}$ (Grifos Nossos)

Dar esmolas aos pobres constituiu uma prática muito comum presente na espetacularização festiva dos funerais barrocos, era sinônimo de confraternização na despedida e um dos últimos gestos beneficiários à economia de salvação, uma vez que a caridade ostentada durante o ritual mortuário repercutia como espécie de favorecimento à absolvição no além. ${ }^{32}$ No entanto, a conversão de parte do seu patrimônio em legados pios demonstra como Ana Oliveira buscou meios compensatórios para remir suas culpas terrenas. Ao retribuir seus escravos "pelos bons serviços prestados", certamente a irmã forra estava pleiteando um lugar seguro no mundo post-mortem. Este gesto reverbera a apropriação simbólica da chamada doutrina de reparação, em que atos de piedade são tidos como

\footnotetext{
${ }^{29}$ AMNSP-SJDR, Livro de óbitos (1790, mar-1792, nov.), Testamento de Maria Correa de Andrade preta Mina aberto em 13/02/1789, anexo ao assento de óbito (11/01/1791).

${ }^{30}$ AMNSP-SJDR, Livro de óbitos (1790, mar-1792, nov.), Testamento de Maria Correa de Andrade preta Mina aberto em 13/02/1789, anexo ao assento de óbito (11/01/1791).

${ }^{31}$ Instituto do Patrimônio Histórico e Artístico Nacional, São João del-Rei, IPHAN-SJDR, Testamento de Ana de Oliveira, 21/09/1779, Testamenteiro: Francisco Fernandes Medela. Livro de registro de Testamentos, n 3, fl. 40.

${ }^{32}$ BORGES, Célia Maia. Escravos e Libertos nas Irmandades do Rosário: devoção e solidariedade em Minas Gerais: séculos XVIII e XIX. Juiz de Fora: editora da UFJF, 2005, p. 168. 
mecanismos de remissão do pecado dentro do catolicismo escolástico, tão entusiasta das "boas obras". 33

Nesse sentido, não só Ana de Oliveira, mas as outras irmãs forras procuraram investir, com afinco, em seus benefícios espirituais e salvação da alma na esfera do além. Essas mulheres rainhas, juízas, mesárias ou simplesmente indicadas como "ocupantes de vários cargos" multiplicaram o número de missas em que lhes eram de direito; beneficiaram filhos, afilhados, maridos e confrades não só no âmbito material, mas também no espiritual (através dos sufrágios); coartaram ou libertaram gratuita ou condicionalmente seus servidores em que viam merecimento em seu comportamento e retribuíram o sentimento devocional construído diretamente com a representação da Virgem, por meio de presentes como adornos femininos, joias e bens imóveis.

Essas doações às entidades leigas e aos aliados de vida terrena, além da afetividade devocional e pessoal demonstram a eficácia da doutrina da piedade e do mutualismo cristão apropriado pelos viveres atlânticos. Esta caridade prevista pela ação das "boas obras" convertia, constantemente, os bens materiais em benefícios espirituais ao doador. Neste aspecto, alianças se fortaleciam no instante derradeiro, uma vez que os receptores da troca, ao receberem a dádiva, retribuíam os ganhos oferecendo ao benfeitor, as orações e missas por sua alma. Sendo assim, o momento ante-mortem servia também como espaço decisivo para a consolidação dessas alianças tecidas ao longo de toda experiência da diáspora, antes e depois do cativeiro. Por seu turno, os significados da economia do dom, vigente nas relações sociais desta sociedade hierárquico-escravista, ultrapassavam efetivamente o aspecto exclusivamente terreno e imediato para atingir as representações e as atitudes perante a morte e a vida pós-túmulo, pois os benefícios materiais e espirituais não eram entendidos separadamente.

Após afirmarmos o protagonismo dessas irmãs na esfera da vivência do sagrado e na participação da administração dos bens simbólicos nos espaços de poder da irmandade, precisamos reconhecer alguns traços comuns observados nessas trajetórias fragmentadas das mulheres devotas que se destacaram nas instâncias hierárquicas da corporação. O primeiro elemento a nos chamar a atenção se refere ao pertencimento ao agrupamento étnico de procedência Mina ou da "Costa da Guiné", nomenclatura do tráfico, genericamente atribuída à região da África Ocidental. Vimos como essas irmãs testadoras forras, majoritariamente de Nação Mina, ocuparam cargos como, juízas e rainhas. Outrossim, essas libertas acumularam patrimônio, teceram redes comerciais de créditos, trabalharam nos negócios da mineração e investiram na posse de escravos, compondo - com essas características um perfil social aproximado à categorização definida por Daniel Precioso ${ }^{34}$ como "elite de cor" na sociedade escravista.

Sheila Faria ${ }^{35}$ demonstrou a capacidade deste grupo étnico, sobretudo das mulheres, em amealhar recursos através do sistema de ganho, ao conseguirem reverter seus pecúlios acumulados do trabalho em escravos, joias e bens móveis e imóveis. Ao lado deste investimento em riquezas, notamos pari passu uma conversão deste patrimônio em pagamentos de esmolas elevadas cobradas pelos cargos de prestígio das irmandades e a aplicação desses recursos em benefícios espirituais e legados pios (bens simbólicos da irmandade). Sendo assim, as mulheres forras, enquanto mesárias, rainhas ou juízas se envolveram nas atividades ligadas ao comércio de retalho, foram donas de vendas, credoras, proprietárias de escravos e construíram alianças consanguíneas e afins, transmitindo seu patrimônio para seus descendentes ou, quando não tinham parentes consanguíneos, distribuíam seus bens entre seus aliados. Legar parte da herança à sua própria alma, instituindo-a como herdeira foi outro gesto comum nas formas de investimento na economia de salvação do catolicismo moderno, muito apropriado pelas mulheres devotas destacadas pela ascensão social da elite de cor do período escravista.

A condição de liberto ou de liberta, associada à procedência étnica, nos ajuda a entender, em parte, a inserção diferenciada dessas mulheres na ocupação desses postos de poder na irmandade. Do total de 71 testadores forros sepultados no Rosário, entre o período de 1782 a 1830, apenas Caetano de Souza não era filiado ao Rosário e $70,42 \%$ dos irmãos forros eram mulheres. Dessas irmãs testadoras,

\footnotetext{
${ }^{33}$ IPHAN-SJDR, Testamento de Ana de Oliveira, 21/09/1779, Testamenteiro: Francisco Fernandes Medela. Livro de registro de Testamentos, $n^{\circ} 3$, fl. 40.

${ }^{34}$ PRECIOSO, Daniel. Legítimos Vassalos: Pardos Livres e Forros na Vila Rica Colonial (1750-1803). São Paulo: Cultura Acadêmica, 2011, p. 63.

${ }^{35}$ FARIA, Sinhás Pretas..., 2004.
} 
$62 \%$ eram minas, $12 \%$ angolas, $8,0 \%$ crioulas, $6 \%$ benguelas, $4 \%$ pardas, $4 \%$ "da Costa", $2 \%$ congas e $2 \%$ couranas. $^{36}$

Esses dados são indicativos, pois reforçam o apontamento historiográfico acerca das habilidades $e$ artifícios mercantis dos grupos étnicos procedentes da África Ocidental. ${ }^{37} \mathrm{~A}$ presença majoritária das associadas pretas minas, entre os testadores, está atrelada à interpretação de o mesmo grupo étnico ${ }^{38}$ recriou na diáspora atlântica não só suas heranças ligadas aos conhecimentos técnicos da extração aurífera, como também colocou em prática suas habilidades mercantis construídas em África. Essas rainhas e juízas desenvolveram, inicialmente, através do acúmulo do pecúlio extraído dos jornais, o excedente necessário para a negociação de sua liberdade. ${ }^{39}$

Nessa perspectiva, a participação incisiva dessas mulheres estrangeiras, procedentes da Costa Ocidental africana, no comércio de retalho - vendas de secos e molhados, quitandas, doces e quitutes do tabuleiro - fez com que as pretas minas potencializassem suas capacidades de amealhar recursos. Isso foi feito através do excedente do sistema de ganho, aumentando, assim, as possibilidades de acumularem pecúlio para a negociação de compra da alforria. Ademais, o domínio da atividade mercantil reporta-se a uma reinvenção de heranças culturais, adaptadas às condições situacionais limitadas pelas adversidades da diáspora, pois a divisão sexual do trabalho das culturas pré-coloniais da atual Nigéria atribuía à mulher o papel de preparo e de comercialização dos alimentos. ${ }^{40}$ Nesse sentido, as atividades mercantis, sobretudo de víveres, integravam um espaço, por excelência, reservado às mulheres da Costa Ocidental africana. Em outro estudo, Ogbomo ${ }^{41}$ assevera que além do comércio ambulante, de porta em porta, as mulheres Esan, neste mesmo território, se dedicaram à produção e venda dos afamados "panos da Costa", com uso tão disseminado entre as libertas $e$ escravas "minas" da sociedade escravista na América Portuguesa.

Esta região apontada, integrava segundo os estudos africanistas, ${ }^{42}$ um território mais amplo denominado, genericamente, como Costa da Mina ou Costa do Ouro. Conhecida como a segunda área do tráfico pela qual mais exportou escravos para o Brasil - superada somente pela região do centro-oeste africano (Congo, Angola e Benguela) - a Costa da Mina abrigava os reinos de Benim, Ardra, Achanti, Oyó e Daomé ${ }^{43}$. Em terceiro lugar havia a rota vinda de Moçambique, abrangendo os limites da África Oriental. James Sweet ${ }^{44}$ adverte que desde o início da expansão marítima do século $\mathrm{XV}$, a Mauritânia (norte da África) e a Alta Guiné, esta em maior escala, forneciam escravos ao Reino de Portugal. No entanto, o comércio de escravos, na sua dimensão atlântica, com demarcações claramente mercantilistas, foi definido em período posterior, com o aprofundamento das alianças entre intermediários lusitanos e sobas (chefes políticos) da África Central.

Nesse período, abrangendo já os séculos XVI e XVIII, as guerras expansionistas ao lado da

\footnotetext{
${ }^{36}$ AMNSP, Testamentos anexos aos assentos de óbitos (1782-1828).

${ }^{37}$ FARIA, Sinhás Pretas..., p. 205.

${ }^{38}$ Entendemos grupo étnico a partir de uma acepção contextual, relacional e dialógica entre as culturas móveis, em situação de contraste. Cf.: BARTH, Fredrik. O guru, o iniciador e outras variações antropológicas. Tomke Lask (org.0 Rio de Janeiro: Contra Capa, 2000, p. 25.

${ }^{39}$ A historiografia voltada para os libertos nos aponta que só os recursos para a autocompra não eram uma prerrogativa suficiente para garantir o consentimento senhorial para dar cabo ao processo de libertação. Era necessário negociar, investir em uma política de longo prazo para obterem, assim, o reconhecimento pelos bons serviços. Esta política de longo prazo não deve ser entendida, portanto, de forma unilateral, pois assim como a liberdade não dependia exclusivamente da vontade do senhor, também não o era de domínio completo do escravo. Com efeito, o investimento na liberdade não se respaldava em garantias legais e, mesmo depois de obtida a tão almejada carta de alforria, o senhor poderia revogá-la, baseando-se no argumento jurídico de que os gestos de ingratidão feriam os códigos de honra senhorial. Cf.: CHALHOUB, Sidney. Visões da Liberdade. Uma história das últimas décadas da escravidão na Corte. São Paulo: Cia das Letras, 1990.

${ }^{40}$ AMADIUME, Ifi. Male Daughters, Female Husbands. London, Zed Books LTD, 1987, p. 39.

${ }^{41}$ OGBOMO, Onaiwu W. Esan Woman Traders and Precolonial Economic Power. In: ERECHI, Felix k. \& HOUSEMIDAMBA, Bessie (orgs.). African market woman and economic Power: the role of woman in African economic development. London, Greenwood Press, 1995, p. 12.

${ }^{42}$ Cf.: CONRAD, Robert Edgar. Tumbeiros. O tráfico de escravos para o Brasil. São Paulo Brasiliense, 1985, p. 39; LOVEJOY, Paul. A escravidão na África: uma história de suas transformações. Rio de Janeiro: Civilização Brasileira, 2002 , p. 100-106; MELLO e SOUZA, Marina de. África e Brasil Africano. São Paulo: Ática, 2007, p. 64-67; SWEET, James, Recriar África: Cultura, parentesco e religião no mundo afro-português (1441-1770), Lisboa, Edições 70, 2007, p. 35; THORNTON, John. A África e os africanos na formação do mundo Atlântico (1400-1800). Rio de Janeiro: Elsevier, 2004, p. $128-151$.

${ }^{43}$ SOARES, Mariza de Carvalho. Devotos da cor: Identidade étnica, religiosidade e escravidão no Rio de Janeiro, século XVIII. Rio de Janeiro: Civilização Brasileira, 2000, p. 72.

${ }^{44}$ SWEET, Recriar África..., p. 31 
construção de mercados especializados serviram como sustentáculos catalisadores do fornecimento da mercadoria humana ao Novo Mundo. Com o avanço do negócio voltado para a venda das gentes etíopes lucraram não só os comerciantes portugueses, mas também os holandeses, franceses, ingleses e até mesmo traficantes brasileiros, representantes dos portos de Salvador e Rio de Janeiro. Esses últimos negociavam diretamente com as praças de Uidá (Costa da Mina), Luanda e Benguela (Angola) respectivamente. ${ }^{45}$

A Costa da Mina ou Costa da Guiné se tornou a principal área de abastecimento entre as décadas de 80 e 90 do século XVII, quando Luanda, importante praça escravista deste momento, foi afetada por uma grave crise de epidemias, fome e seca, além dos constantes conflitos políticos gerados em função das disputas pelo monopólio das rotas e mercados de escravos. Como alternativa, os "mercadores brasileiros da Bahia e de Pernambuco reagiram, desviando as suas atenções para a chamada Costa da Mina, localizada no território que hoje faz parte do Benim". "Deste vínculo comercial direto, escravos eram trocados por tabaco, principal moeda do tráfico nesta região africana, ao lado da geribita (cachaça), produto muito apreciado nos mercados de Luanda e de Benguela.

Na região da Alta Guiné, os traficantes baianos e os comerciantes de Uidá estreitaram seus vínculos mercantis, ao ponto de muitos mercadores nascidos em Salvador formarem famílias nessas cidades como Uidá e Lagos e se aliarem aos chefes políticos locais. ${ }^{47} \mathrm{Com}$ a expansão da produção aurífera nos sertões das Minas, os escravos da Costa da Mina, falantes das línguas ioruba, fon, Gegê tornaramse, até as primeiras décadas do século XVIII, as principais fontes de mão de obra, disputados pelas camadas senhoriais em função do conhecimento que tinham das técnicas de fundição e pelas habilidades na atividade da extração. ${ }^{48} \mathrm{Na}$ Irmandade de São João, os entrantes desta procedência, potenciais fundadores da irmandade, tiveram uma participação decrescente nos anos finais do Setecentos e primeiras décadas do século seguinte, conforme aumentou o contingente centro-africano em razão das mudanças das rotas do tráfico atlântico. ${ }^{49}$

Todavia, para maiores esclarecimentos desta apropriação da nomenclatura do tráfico pelos estrangeiros, devemos notar que embora o termo "mina" faça alusão direta ao mercado de São Jorge da Mina, deve ser tratado com cuidado, pois o vocábulo é impreciso, na medida em que a expressão reporta-se a um porto de embarque e não ao grupo étnico de origem. Sendo assim, os grupos étnicos se constituíram nas relações permanentes de contatos culturais e no caso das etnias africanas reconstruídas no Brasil, absorveram, em grande parte, as generalizações provenientes da própria classificação do tráfico, fator este que contribuiu demasiadamente para obscurecer identidades mais específicas da pré-travessia. Deste modo, os grupos classificados como minas no porto carioca poderiam abranger diferentes grupos étnicos. Por outro lado, a qualificação mina em Salvador poderia encobrir ou recriar uma grande variedade de segmentos, tais como os hauças, os iorubás, os fulas, os calabares, os nagôs, os gêjes, os makis, os fons, os achantis e uma série de outras procedências adjacentes da África Ocidental. ${ }^{50}$

Não obstante, havia um discurso legitimador acerca das formas aceitáveis e reprováveis de escravização em várias culturas do continente africano. O comércio, por exemplo, não era o principal

\footnotetext{
${ }^{45}$ Sobre o trato direto entre comerciantes brasileiros e africanos, cf.: ALENCASTRO, Luis Felipe de. O trato dos viventes. Formação do Brasil no Atlântico Sul. São Paulo: Companhia das Letras, 2000; FLORENTINO, FLORENTINO, Manolo. Em costas negras. Uma história do tráfico de escravos entre África e o Rio de Janeiro. São Paulo: Companhia das Letras, 2002.

${ }^{46}$ SWEET, Recriar África..., p. 33.

${ }^{47}$ Francisco Félix de Souza foi um dos traficantes de escravos baianos que se estabeleceu em Benim. Na primeira metade do século XIX o comerciante se tornou o principal aliado do Reino de Daomé e intermediário entre os mundos: europeu, africano e luso-americano. Recebeu do soberano de Daomé o título Chachá, absorveu os costumes locais, como a poliginia, por exemplo, e deixou uma descendência numerosa no local. Para mais informações, ver: SILVA, Alberto da Costa e. Francisco Félix de Souza, o mercador de escravos. Rio de Janeiro: Nova Fronteira, 2004. SOUZA, Monica Lima e. Entre margens: o retorno à África de libertos do Brasil (1830-1870). 2008, 271p. Tese (Doutorado em História). PPGH/UFF, Niterói.

${ }^{48}$ RUSSELL-WOOD, A. J. R. O comportamento coletivo: as irmandades. In: RUSSELL-WOOD, A. J. R. Escravos e Libertos no Brasil Colonial. Rio de Janeiro: Civilização Brasileira, 2005, p. 169.

${ }^{49}$ Segundo Brügger \& Oliveira, "Já é usual, na historiografia sobre escravidão em Minas Gerais, a afirmação de que, num primeiro momento dos setecentos, predominaram os cativos de origem mina, desembarcados, sobretudo, na Bahia $e$ remetidos para as terras mineiras." Cf.: BRÜGGER, Silvia \& OLIVEIRA, Anderson J. M. de. Os Benguelas de São João Del Rei: tráfico- atlântico, religiosidade e identidades étnicas. (Séculos XVIII e XIX). In: Revista Tempo, v. 13, n² 26, Niterói-RJ, 2009, pp. 177-204.
}

${ }^{50}$ KARASCH, Mary C. A vida dos escravos no Rio de Janeiro 1808-1850. São Paulo, Companhia das Letras, 2000 , p. 64. 
mecanismo de abastecimento de escravos, mesmo que mercadores muçulmanos já incluíssem a mercadoria humana entre seus negócios naquela região. A escravidão na Costa da Guiné desempenhava, na visão de Lovejoy $^{51}$, um papel complementar, incidental, antes da inserção europeia, pois as relações servis dependiam muito mais do sistema de interação dos grupos familiares ao integrar o escravo como membro agregado à família - do que das transações exclusivamente mercadológicas. O autor também descreve que havia uma hierarquização na condição servil, pois dependendo do setor em que se destinava o escravo, diferente era o status no qual ele poderia ocupar frente aos segmentos da sociedade. Sendo assim, era possível assumir não só encargos manuais (trabalho braçal das lavouras, o comércio e serviços domésticos), mas também aqueles voltados para postos burocráticos estatais.

Além disso, a escravidão não se transmitia, obrigatoriamente, pelo ventre da mãe, como ocorria na legislação portuguesa. Quando compradas para servirem como concubinas, as mulheres escravas poderiam gerar filhos livres, desde que fossem filhos do senhor. Na prática islâmica, as mulheres "tornavam-se legalmente livres com a morte" do seu proprietário, em alguns casos elas já eram consideradas automaticamente livres assim que davam a luz aos filhos de seus amos. ${ }^{52} \mathrm{~A}$ manumissão também integrou uma prática reconhecidamente instituída no mundo islâmico africano, haja vista a libertação dada pela autocompra ou por via da quitação efetuada por terceiros (lembrando o valor de mercado sempre mais oneroso para as mulheres), ou por meio da prestação de serviços e extensão das relações de subserviência ao antigo senhor. Andrea Lisly Gonçalves ${ }^{53}$ descreve a existência de estágios intermediários entre os escravos manumitidos, de forma condicional, e aqueles que conseguiram a libertação plena. Nas áreas shelo-sudanesas os escravos manumitidos deveriam morar com seus antigos senhores e não poderiam se deslocar sem sua autorização prévia. Já os escravos definitivamente libertados, gozavam de plena autonomia de deslocamento e não se prendiam com laços clientelares a seus antigos senhores.

Todavia, a instituição da escravidão e as práticas de manumissão já eram conhecidas do outro lado do Atlântico, sob outros vieses locais. No Novo Mundo, as especificidades da experiência urbana do cativeiro - através da expansão da prestação de serviços e do sistema de ganho - possibilitaram o acesso de alguns grupos de escravos à compra da alforria. Mas não só as justificativas econômicas servem para explicar o fenômeno da libertação em Minas; outras motivações como as habilidades para lidar com as pressões morais do cativeiro, a aquisição de aliados ou protetores (eventuais mediadores na negociação com o senhor) e os próprios interesses afetivos senhoriais devem ser levados em consideração. Os jornais e, porventura, seus excedentes, auxiliaram, sem dúvidas, na acumulação do pecúlio, no entanto, só a reunião de recursos não era suficiente; era preciso barganhar, adquirir confiança, prestar "bons serviços" durante uma vida inteira.

Nessa disputa pelos "prêmios" ou "dádivas", as mulheres escravas saíram na frente, com amplas vantagens em relação aos homens. Esta primazia feminina pode ser explicada tanto por suas habilidades em amealhar recursos (através das vendas de seus tabuleiros), quanto por suas inserções na casa grande, via prestação dos serviços domésticos. As motivações de ordem afetiva e sexual também poderiam ser definidoras nesse processo, mas para isso essas cativas articulavam laços de reciprocidade com seus senhores, negociavam os "ganhos", tomados aparentemente "dádivas" ou a "premiações" por parte dos senhores. ${ }^{54}$

Destarte, vale salientar que em situações como esta sempre envolvia uma relação dual, às vezes mediada por aliados coparticipes, mas nunca decidida por uma via de mão única. Ademais, as redes de parentesco ou mesmo as irmandades (através dos seus resgates de irmãos) ${ }^{55}$ poderiam se envolver

\footnotetext{
${ }^{51}$ LOVEJOY, A escravidão na África..., p. 49.

${ }^{52}$ LOVEJOY, A escravidão na África..., p. 30.

${ }^{53}$ GONÇALVES, Andréa Lisly. As Margens da Liberdade. Estudo sobre a prática das alforrias em Minas colonial e provincial. Belo Horizonte: Editora Fino Traço, 2011, p. 32.

${ }^{54}$ Ao abordar sobre o tema da exploração sexual presente nos processos de alforria, França Paiva chama atenção para os interesses de ambas as partes nesta relação de trocas. Mesmo se tratando de posições sociais e de uma reciprocidade absolutamente desiguais e sem minorar, portanto, a violência intrínseca nessas relações, o autor reitera que não se pode descartar o agenciamento dessas mulheres para da alforria ou a transmissão de recursos materiais e a assistência aos "filhos ilegítimos". Cf.: PAIVA, Eduardo França. Escravos e libertos nas Minas Gerais do século XVIII: estratégias de resistência através dos testamentos. São Paulo: Annablume, 1995, p. 116-117.

${ }^{55}$ Sobre os processos de resgate de irmãos escravos do cativeiro considerado "injusto", ver: BRÁSIO, Antônio. Os pretos em 380 SÆCUlUM - Revista DE HistóRIA [39]; João Pessoa, jul./dez. 2018.
} 
neste processo de libertação. A instituição da alforria fixou, portanto, uma das pedras basilares do sistema escravista, ao mesmo tempo em que atendia aos interesses dos seus contemplados, disseminava também uma política de domínio em que a dívida de gratidão não poderia ser quitada somente com recursos financeiros.

França Paiva, ${ }^{56}$ ao reiterar a participação ativa das mulheres na aquisição da alforria, acrescenta que as pretas forras representaram o segundo grupo mais rico da sociedade mineira, depois dos homens livres (entre os quais, os portugueses), superando até mesmo a acumulação de bens das mulheres livres e dos pretos forros. Além disso, esta prosperidade econômica das libertas, sobretudo das pretas minas, se deve não só às aos seus arranjos sociais em que foram capazes de acionar nos quadros da diáspora, mas as heranças culturais recriadas com significados apropriados às limitações da sociedade escravista. O legado transmitido por essas irmãs forras em seus testamentos diz respeito tanto aos bens materiais, quanto às práticas imateriais, impressas na forma de ensinamentos e técnicas repassados aos herdeiros em legados de instrumentos de trabalho como tachos de cobre para fabricação de doces, balanças de ouro, instrumentos de mineração, etc. ${ }^{57}$.

Já a distribuição dos legados pios pelas testadoras à devoção do Rosário e a conversão de parte deste patrimônio em benefícios espirituais demonstram como as irmãs matriculadas, quando bem posicionadas socialmente, tinham inserções maiores na ocupação de cargos hierárquicos de prestígio na irmandade. Brügger e Oliveira, ${ }^{58}$ em pesquisa publicada pela Revista Tempo, chamaram atenção para este fato ao indicar a participação de 21 mulheres entre os 24 minas ocupantes de cargos entre 1750 a 1848 na irmandade do Rosário de São João del-Rei. Para os autores, os pretos minas "provavelmente estiveram entre os fundadores da irmandade" e representavam no mesmo período mencionado, o terceiro grupo mais influente do sodalício, com 18,6\% dos cargos, superados apenas pelos crioulos $(37,2 \%)$ e angolas $(19,4 \%)$. Em vista disto, o destaque às mulheres minas ocorreu mesmo durante a vigência do tráfico em que os grupos centro-africanos dominavam o panorama demográfico da população escrava, sem contar o avanço da crescente "crioulização", isto é, dos escravos nascidos no Brasil, nas décadas.

\section{Considerações Finais}

Neste artigo, procuramos abordar - de forma não conclusiva, mas provocativa - os mecanismos de agenciamento e de mobilidade social das pretas minas do Rosário de São João del-Rei. Argumentamos, através da análise de testamentos e do acervo documental da Irmandade, que as irmãs, embora afastadas oficialmente dos poderes decisórios da confraria - conforme prescreviam as normatizações estatuárias - exerceram funções de mando dentro da agremiação, principalmente nos setores informais, como os juizados de promessas, os reinados e a organização dos banquetes festivos. Foram elas também a protagonizar papéis decisivos na arregimentação de esmolas para a organização dos ritos em homenagem ao orago da corporação, ao ocuparem, com maior frequência do que os homens, os cargos de juízas de santo e rainhas. Além disso, chamamos a atenção para o caráter definidor das "heranças e recordações" re-significadas no contexto da escravidão, ao centralizarem, nas praças mercantis de mineração, o ofício do comércio ambulante. As devotas testadoras de procedência mina protagonizaram espaços de mobilidade social, através das atividades de ganho, $e$ ampliaram seu capital simbólico se tornando rainhas e juízas do Rosário. Deste modo, adquiriram notoriedade dentro e fora da irmandade: acumularam pecúlio, se tornaram senhoras de escravarias $e$ donas de "vendas", emprestaram dinheiro a juros, investiram em terras de minerar, expandiram suas redes de aliados e seus laços identitários, através do parentesco confraternal e construíram espaços de coesão étnica e de perpetuação nos cargos mentores da sociabilidade festiva, como o de rainhas do Rosário.

\footnotetext{
Portugal. Lisboa: Divisão de Publicações e Biblioteca (Agência Geral das Colônias), 1944, p. 73 e LAHON, Didier. Da redução da alteridade a consagração da diferença: as irmandades negras em Portugal (Séculos XVI-XVIII). In.: Revista Projeto História. São Paulo, n 44, pp. 553-83, jun. 2012, p. 60.

${ }^{56}$ PAIVA, Escravos e libertos nas Minas Gerais do século XVIII..., p. 36.

${ }^{57}$ FARIA, Sinhás Pretas..., p. 243.

${ }^{58}$ BRÜGGER \& OLIVEIRA, Os Benguelas..., p. 193.
} 


\section{RESUMO}

O presente artigo tem por objetivo analisar os processos de mobilidade social das irmãs pretas forras da Costa da Mina e seus investimentos em bens materiais e simbólicos da irmandade do Rosário de São João del-Rei, entre a segunda metade do século XVIII até meados dos Oitocentos. Nossa arguição procura demonstrar que, apesar do afastamento das atividades formais da agremiação, essas mulheres construíram estratégias de inserção e espaços de poder importantes dentro da irmandade. Todavia, o alcance deste protagonismo nos altos escalóes da confraria reporta-se não só ao agenciamento situacional na diáspora atlântica, mas às "heranças $e$ recordações" re-significadas na experiência da sociedade escravista no Novo Mundo. Para tanto, foram utilizados os testamentos das irmãs forras e a documentação confrarial, tais como: livros de compromissos e os assentos de matrículas.

Palavras-chave: Irmandade do Rosário; Testamentos; Pretas minas.
This article aims to analyze the social mobility processes of the black sisters freed Costa Mine and its investments in material and symbolic goods of the Rosary brotherhood of São João del Rei, between the second half of the eighteenth century to the middle of the nineteenth century. Our complaint seeks to demonstrate that, despite the departure from the formal activities of the association, these women built insertion strategies and spaces of important power within the fellowship. However, the scope of this role in the high echelons of the Brotherhood refers not only to situational agency in the Atlantic Diaspora, but the "heritage and memories" re-signified the experience of slave society in the New World. To this end, we will the blinders sisters and documentation of the brotherhoods were used, such as appointments books and enrollment seats.

Keywords: The Rosary Brotherhood; Wills; Black mines.

Artigo recebido em 07 fev. 2017.

Aprovado em 16 mai. 2018. 